\title{
PURE - Public Understanding of Renewable Energy
}

\author{
Lars Broman ${ }^{1, *}$, Tara C. Kandpal ${ }^{1,2}$ \\ ${ }^{1}$ Strömstad Academy, SE-45280 Strömstad, Sweden \\ ${ }^{2}$ Centre for Energy Studies, Indian Institute of Technology IIT-Delhi, Delhi 11001, India \\ * Corresponding author. Tel: +46 708810 178, E-mail: lars.broman@stromstadakademi.se
}

\begin{abstract}
Public understanding of science PUS is a central concept among science communicators. Public understanding of renewable energy PURE is proposed as an important sub-concept of PUS. The aim of our paper is to interest and invite renewable energy scientists to join a PURE research project. Four separate important questions for a PURE research project can be identified: (A) Is PURE important? (B) Which issues of PURE are the most important ones, according to renewable energy scientists? (C) What understanding of renewable energy has the general public today, worldwide? (D) How to achieve PURE?
\end{abstract}

Keywords: Public understanding of science, PURE, Renewable energy, science communication, science centre.

\section{Introduction and Definitions}

Public Understanding of Science is today an established concept. There is even since 1992 a scientific journal with this name. The concept is usually referred to as PUS. Bauer [1] has given a 3-fold definition of PUS: (1) "Debunking of superstitions, half-knowledge, complete and utter ignorance, misunderstanding and mumbo-jumbo, and virulent memes that give rise to anti-science." (2) PUS is to "improve science literacy, to mobilize favourable attitudes in support of science and new technology, to increase interest in science among young people and other segments of society, and to intensify public's engagement with science in general and for the greater good of society." (3) "PUS considers common sense as an asset" and PUS research should "chart out the public controversies arising from new developments and in different regions of the world" exemplified by "the impact of the climate of opinion on knowledge production."

During the planning of Sweden's first science centre The Futures' Museum, one of the authors (Broman) gave seven reasons for creating a science centre [2], slightly revised [3]: (1) Give an insight that science is understandable. (2) Awaken curiosity. (3) Give people the courage to experiment. (4) Facilitate public understanding of science. (5) Provide preparedness to withstand superstition and pseudoscience. (6)Amuse and entertain. (7) Provide aesthetic experiences. The reasons have been described in some detail in English elsewhere [4]. Reason (4) is in line with Bauer's definitions (2) and (3), and reason (5) coincides with Bauer's definition (1).

Underlying the statements is the notion that PUS is important, which scientists happily believe, and we of course agree, but it is not as simple as that. There are e.g. so many different sciences (which in turn are divided into many disciplines). A rather popular notion is that "science" is that same as "natural sciences", but that is not the case. Again citing Bauer, science also "includes engineering and medicine, the social sciences and humanities, old and new disciplines with clear boundaries, but also ... fuzzy transdisciplinary techno-sciences." But maybe all different disciplines are not equally important that the public understands?

It is also vital to identify target groups, since some may be more important than other. Loosely defined target groups frequently mentioned are young people (in the world of science centres often restricted to the "7-eleven group" of elementary school children), voting adults, 
and decision makers. Other interesting groups may include teenagers, refugees, religious fundamentalists, senior citizens, people living in villages as well as cities, just to name a few.

It is also important to identify groups of science communicators. As an example, The European Science Communication Network ESCOnet, 2005-8 developed and conducted a series of workshops on science communication training aimed at young post-doc researchers [5].

Since renewable energy is our main interest, the authors have decided to investigate a sub-set of PUS, namely public understanding of renewable energy PURE. The remainder of this article attempts to give a starting point of a potential research project on PURE. The main questions are "is PURE important?" and, if the answer is yes, "how could PURE be achieved, and which means of achieving PURE are potentially useful?"

\section{On the Importance of Public Understanding of Renewable Energy}

There are several reasons why public understanding of renewable energy might be important. Four of them are these:

(1) The earth is a lonely planet in a vast space, not as crowded as the impression one gets from science fiction movies. For humans to move from a destroyed earth to another hospitable planet is just impossible.

(2) The earth is a planet alive with a dead sister and a dead brother. Venus is too hot for life due (also) to too much greenhouse gas, while Mars is too cold due (also) to too little greenhouse gas.

(3) Anthropogenic influence on the world's climate, in particular climate warming due to release of greenhouse gasses like carbon dioxide $\mathrm{CO}_{2}$ and methane $\mathrm{CH}_{4}$ is generally agreed upon among [6].

(4) One major source of greenhouse gases is combustion of fossil fuels, which has to be replaced by increased energy efficiency and large-scale worldwide dissemination of appropriate technologies for harnessing renewable sources of energy.

A reasonable conclusion is that public understanding of renewable energy is important. An important task of a research project on PURE would be to identify pros and cons in this respect. There are also several attendant questions: What do professionals - researchers, planetarians, teachers - say? How interested is the public - and different target groups - in renewable energy, and what do they already know? Which disciplines in renewable energy science are more important than others? A very crucial role exists of common people in the success of this objective of large scale harnessing of renewable sources of energy, since as adoption as well as design, developing, manufacturing etc, would require their participation.

\section{How Could Public Understanding of Renewable Energy be Achieved, and which Means are Potentially Useful?}

There are of course several different channels that can be and are used in conveying attitudes towards and knowledge of renewable energy subjects: Newspapers, TV programs, books, interactive exhibits in science centres, lessons in the school. Different media certainly attract different target groups. One of the tasks for the project to find out is of course how science 
centres with interactive exhibits can be used for the envisaged purpose i.e. PURE. It is even not possible to judge all centres the same - it is of course a great difference between large science centres (like Nehru Science Centre in Bombay, Cité de Science and Technologie in Paris or Exploratorium in San Francisco) and small ones (like Ekohuset in Strömstad and Molekylverkstan in Stenungsund; both Sweden).

As has been shown by several authors, among them Franck Pettersen in a master thesis [7], is that a combination of watching a planetarium show and doing experiments related to the show is very useful. (Planetariums used to be devoted basically to astronomy using a classical optomechanical star projector. Increasingly, planetariums today concentrate on edutainment shows with astronomic content, using all-dome video technique. Shows related to climate change and its solutions would be easily produced using modern planetarium projectors and would fit nicely under the planetarium dome.) Here are two other voices on interactivity:

Michael Spock, former Director of Boston Children's Museum, borrowed the Chinese philosopher Confucius' proverb as a motto for the museum: I hear and I forget, I see and I remember, I do and I understand (cited in [8]).

William Glasser wrote [9]: We learn $10 \%$ of what we read, $20 \%$ of what we hear, $30 \%$ of what we see, $50 \%$ of what we both see and hear, $70 \%$ of what is discussed with others, $80 \%$ of what we experience, and $95 \%$ of what we teach.

An important component of achieving PURE is likely to be interactivity and hands-on experience, and useful environments for this are science centres. Some examples of this are shown elsewhere [10] in photographs from the Teknoland outdoor science centre 2000-2001: Yourself a Sundial, Toddlers' Teknoland, Solar Energy Surfaces, The Greenhouse, and The Solar Heated Chess Board.

\subsection{Popular Education of Renewable Energy through IASEE and ISREE}

International Association of Solar Energy Education IASEE started in December 1989. In September 1990, IASEE became the International Solar Energy Society ISES Working Group on education (see e.g. [11]). Also since 1991, IASEE has arranged a series of symposiums, International Symposium on Renewable Energy Education ISREE, held every or every second year, sometimes as part of the biennial ISES Solar World Congress. At each symposium, between 10 and 30 papers were presented. Most papers have dealt with education in schools and at university level, and certainly school children and university students are important target groups, but here we will concentrate ourselves on the general public.

One of the 1991 ISREE papers presented was On the Need for Solar Energy Education [12]. In this paper, elementary and secondary school education, vocational training, university courses, educating decision makers, and educating the general public are treated. An excerpt from the paper reads (slightly edited):

\section{EDUCATING THE GENERAL PUBLIC}

Ordinary people are the ultimate utilizers of energy from the sun and accordingly need basic knowledge in how to make use of this new technology and be motivated to use it. A number of ways to educate large populations are readily available. Some proven examples: 
Mass media. This includes newspapers, weekly magazines, radio, and TV. You address professional journalists, and if you manage to teach them some basic facts, they will frequently make o good job in popularizing what they have learned.

Exhibitions. We have built both Science Centre exhibitions (1986 and 1990 on solar measurements for the Futures' Museum in Borlänge, Sweden) and travelling exhibitions (Alternative Energy 1976, Solar Energy Exhibition 1989 [13]). The educational value of an exhibition is greatly improved if it provides hands-on experiences.

Another kind of exhibition is the trade fair with commercial and institutional exhibitors. Such fairs can range in size from the one hundred $\mathrm{m}^{2}$ or so of exhibits that accompany SERC's Solar Energy Days to the multi-acre exhibition of the UN Conference on New and Renewable Energy Sources of Energy in Nairobi 1981. Such fairs contain up-to-date technological information for many categories of visitors and should be made available both to professionals and to the general public.

Lectures, etc. General admission popular lectures sometimes attract good-size crowds, especially if arranged as debates or panel discussions, or if a well-known speaker is featured. Lectures can also be video-taped, and can, with appropriate solar powered equipment, be shown just about anywhere (see [14]).

Community college courses. These are excellent in giving interested individuals more-than-basic knowledge. The aim of such courses can even be that every participant builds his own solar collector (see [15]).

Another paper at ISREE'91 dealt with renewable energy education and training in an Egyptian village with a programme consisting of public presentations, group discussions, simple solar kits, children competitions, technical training workshops, exhibits with working models, working systems, video-training systems, and a communal library [14].

A regional training workshop was held in Libya in December 1990 with the objective of familiarizing women in developing countries with renewable energy development and technology; the workshop was presented at ISREE'92 [16].

A community college type of educating people that is popular in Sweden is called study circles. A typical study circle consists of a circle leader - the teacher - and 5-10 participants. Especially during the 1990ies, knowledge about solar heating was spread in many locations in Sweden in this form, where each study group built a solar heating system at one of the participants' house, using a popular build-yourself solar collector kit; this was presented at ISREE'93 [15]. A thorough investigation of this kind of education is a case study done by Henning [17].

The importance of public understanding of renewable energy was dealt with at ISREE'02 [18]. In this paper, a result from SAS [19] was cited:

The study Science and Scientists (SAS) asked ten thousand (10 000) 13-year old pupils in 21 countries:

"What do you want to learn about?" 
"New sources of energy - sun, wind"

was among the $25 \%$ least popular answers, and it was much less popular among girls than among boys.

* Why is it so?

* Should we do something about it?

* If so, how?

* Why is it so?

Pupils - and adults - are interested in scientific and technological subjects for a number of reasons:

* Economical reasons

* Usefulness

* Interesting, fun

* Relevant

Renewable energy obviously does not meet these requirements! At ISREE'02, the rhetorical question Should we do something about it" was answered with a Yes! followed by If so, how? and a try to answer [18]:

* Visibility of renewable energy is important

* The school is important

* Media are important

* Exhibitions, Science Centres and Science Parks could be used to meet people of all ages.

Experiences from using science centre exhibits in educating the general public on renewable energy were presented at ISREE'03 [10].

\subsection{Renewable Energy Dissemination at Village Level}

A large proportion of the Earth's population is rural, and their quality of life could be improved at the same time as their impact affection on climate is decreased by introduction of renewable energy utilization at village level: "Low carbon technology for low-purchasing power people." This includes a multitude of technologies and education of users is therefore critically important. A good example is dissemination of family size biogas plants in India - to date 4 million units and the aim to increase the number of plants to 12 million.

Another example: Electricity for light has quickly become affordable by the development of low-cost white high-intensity low-energy light emitting diodes (LED). Mobile phones are spreading rapidly also among rural people in developing countries, and these are effectively charged using the same small not-so-expensive photovoltaic (PV) modules used for powering LED lamps.

When educating rural people, it should be understood that many people live below the poverty line and that illiteracy is common. It is not always easy as the following example may illustrate [20]. Egyptian authorities wanted in the early 1980ies to implement solar collectors for water heating in a rural area. The farmers however refused to use them for from their point of view good reasons. In an earlier campaign in the same area, authorities had tried to introduce family planning, and the local people suspected that this new technology was just another attempt to decrease their fertility. 


\section{A PURE Research Project Proposal}

As obvious from the preceding chapters, we have for several years been interested in public understanding of renewable energy. We believe however that presently this concept is more important than ever. An interdisciplinary and international science communication project on public understanding of renewable energy is proposed with the hub at Strömstad Academy (www.stromstadakademi.se) in Sweden. It should include both research on the importance of PURE and on the impact of different methods to achieve PURE including determining which methods are best adapted for different target groups.

This means that different target groups have to be approached from renewable energy specialists and energy policy makers to school teachers [21], engineering students [22] and different kinds of end-users. A variety of methods, such as questionnaire studies, interviews and focus groups, should be considered.

We have made a start by supervising Science Communication master students and teacher students at Dalarna University during the last decade. Some of them have written their theses on the impact of experimenting with renewable energy at science centres on school pupils in ages 6 to 18. One example is the thesis of Harahsheh [23], indicating a measurable impact on 15-yr. old pupils on their attitude towards renewable energy.

There is however much more that need to be done. A possible start could be a questionnaire distributed world-wide to a well-defined target group (such as visitors to science centres) aiming at finding out the present level of public understanding renewable energy. We would also like to know how renewable energy scientist grade different topics in PURE.

Please contact us if you would like to participate in the PURE project. The corresponding author's email address is found at the top of the article.

\section{References}

[1] M.W. Bauer, Editorial, Public Understanding of Science 18, 2009, pp.378-382.

[2] L. Broman, Populärvetenskapliga centra växer fram i Sverige (Science Centres are Growing Up in Sweden), Svenska Museer 1/1984, pp. 7-12. (In Swedish.)

[3] L. Broman, Kommunicera vetenskap och extramuralt lärande (Communicating Science and Extramural Learning), in E. K. Henriksen and M. Ødegaard, editors, Naturfagenes didaktikk - en disiplin i forandring?, Norwegian Academic Press, pp. 503-513 (in Swedish).

[4] L. Broman, Multiple Interests - a Hypothesis with Possible Implications for Science Centers, in C. Michelsen, editor. NNORSC-2005 Proceedings Report from Odense University, Denmark, 6 pp.

[5] S. Miller, D. Fahy, and The ESConet Team, Can Science Communication Workshops Train Scientists for Reflexive Public Engagement? Science Communication 31, 2009, pp.116-126.

[6] IPCC Intergovernmental Panel on Climate Change IPCC Climate Change 2007: Fourth Assessment Report. www.ipcc.ch.

[7] F. Pettersen, Master thesis on informal learning at University of Oslo (unpublished). Results were presented at the 12th Nordic Planetarium Association Conference, Oslo 6-8 October 1995. 
[8] A. Ott, Forum för lärande (Forum for learning), compendium from Göteborg University 2001 (in Swedish, unpublished).

[9] W. Glasser, The Quality School, Harper \& Row, 1990.

[10]L. Broman, Solar Energy Studies and Extramural Learning. Proc. ISES Solar World Congress, https://shop.ises.org/bookshop/pages/displayBook.xsp?id=16.

[11]K. Blum, L. Broman, and S. Niwong, This is IASEE, ISES' Working Group on Education, Progress in Solar Energy Education 3, 1994, pp. 1-2.

[12]L. Broman and A. Ott, On the Need for Solar Energy Education, Progress in Solar Energy Education 1, 1992, pp. 23-25.

[13]L. Broman and K Gustafsson, An Educational Travelling Exhibition on Solar Energy, Proc. ISES Solar World Congress, Denver, USA, 1991, pp 3849-3852.

[14]S. Arafa, Renewable Energy Education and Training at the Village Level, Progress in Solar Energy Education 1, 1992, pp. 1-4.

[15]K. Börjesson, K. Gustafsson, and K. Lorenz, The Spreading of Solar Energy Now-How Through Educating Homebuilders, Progress in Solar Energy Education 3, 1994, pp. 1920.L. Broman and A. Ott, On the Need for Solar Energy Education, Progress in Solar Energy Education 1, 1992, pp. 23-25.

[16] M.F. Bara, and M. A. Muntasser, Renewable Energy Education and Training for Women in Developing Countries, Progress in Solar Energy Education 2, 1993, pp. 1-2.

[17]A. Henning, Ambiguous Artefacts. Solar Collectors in Swedish Contexts. On processes of Cultural Modification, pp 177-232. Stockholm Studies in Social Anthropology 44, Almqvist \& Wiksell International. ISBN 9172650346, 2000.

[18]L. Broman, On the Importance of Public Education and Public Understanding of Renewable Energy. Luncheon presentation at the 8th International Symposium on Renewable Energy Education, Orlando, Florida, 2002.

[19]S. Sjøberg, Naturvetenskap som allmänbildning (Science as General Knowledge). Studentlitteratur. ISBN 9144009992, 2000.

[20]I. Sakr, Private communication at 1st International Conference on Solar Energy Optics in Kromeric, Czechoslovakia, 1984.

[21]T.C. Kandpal and S.S. Mathur, Solar Energy Experiments for School Level Students. Proc. Indian National Solar EnergyConvention. Allied Publishers Ltd., New Delhi, 1982.

[22]H.P. Garg and T.C. Kandpal, Renewable Energy Engineering Education. Omega Scientific Publishers, New Delhi, 1996.

[23]S.S. Harahsheh, (Lars Broman, supervisor), How the Energy-Hunting Project Affected the Intention of Eight Grade Pupils towards their Future Education and Career in Natural Science and Technology in Compulsory Schools of Borlänge, Sweden. Thesis HDaSciCom-38, 2007. 